\title{
Entre a metrópole e a colônia: dramaturgia e cena teatral no Brasil (1711-1822)'
}

\author{
Evelyn Furquim Werneck Lima*
}

Na segunda metade do século XVIII, o progresso econômico e as exigências das instituições civis e religiosas que, pouco a pouco foram sendo criadas no Brasil à luz da metrópole, induziram a uma intensa produção cultural de bens arquiteturais, pictóricos, escultóricos e literários que apresentam a influência das Luzes. As práticas teatrais, em especial a dramaturgia luso-brasileira e a construção de edifícios teatrais nas cidades litorâneas e na região aurífera, também refletem esta efervescência. Entretanto, vários historiadores do teatro brasileiro referem-se a um "vazio teatral" abrangendo os séculos XVII e XVIII. Concordamos que até o início do século XVIII, imperava o teatro jesuítico - visando à catequese dos indígenas - e que até meados do XVIII, havia, com freqüência, grandes comemorações públicas voltadas para festas religiosas e profanas nas cidades e vilas coloniais do Brasil. Entretanto, considerando a existência de várias Casas de Ópera e embora não se possa referir uma dramaturgia genuinamente brasileira - pois, até 1822, o Brasil era completamente dependente de Portugal, polemizo com Sabato Magaldi (1996) e Décio de Almeida Prado, (2003: 42): visto que muitos autores foram encenados no Brasil com peças já escritas em português e para um público de portugueses e mestiços, que processava o amálgama cultural entre a metrópole e a colônia. Acreditamos que seja necessário entender as contradições, antagonismos e sincretismos do período estudado, pois como afirma Ruth Gauer, as diferentes verdades contidas no modelo social brasileiro não são irredutíveis. A presença das relações tradicionais e contemporâneas e das relações que não se circunscreviam nesta historicidade, como a dos nativos e dos negros, dimensionavam a configuração da cultura brasileira de então. (Cf. GAUER, 1997: 567-591).

Em Portugal, os teatros populares do Bairro Alto, da Rua dos Condes, do Salitre e da Graça encenavam principalmente os melodramas de Metastásio, comédias de Goldoni e de Molière, tragédias de Racine e Voltaire, além de farsas e entremezes, muitas vezes autônomo. O Marquês do Pombal encomendou a tradução de 'Tartufe', de Molière, que foi encenado e teve a sua presença como espectador na estréia. Do mesmo modo, o teatro lírico no reinado de D. José gastava 40.000 coroas por ano, um valor bastante significativo para a época. $\mathrm{O}$ alvará de 1771 declarou a profissão de ator isenta de infâmia, apontando as vantagens que o teatro poderia proporcionar ao povo e aconselhava a construção de teatros públicos, pois estes eram considerados "escolas onde os povos aprendem as máximas sãs da política, da moral, do amor à pátria, do valor, do zelo e da fidelidade com que devem servir aos soberanos." (Apud SOUZA, 1960.)

* Profa adjunta do Departamento de Teoria do Teatro e do Programa de Pós-Graduação em Teatro da Universidade Federal do Estado do Rio de Janeiro - Unirio. Pesquisadora da CAPES em estágio pós-doutoral (Paris X-Nanterre), Membro do Conselho Municipal de Proteção do Patrimônio Cultural do Rio de Janeiro. Autora entre outros, do livro Arquitetura do Espetáculo (2000). Desenvolve pesquisa sobre o Espaço Teatral. Pesquisadora do CNPq. 
No Brasil, era particularmente apreciada a peça Les Fourberies de Scapin, de Molière, traduzida em Lisboa pelo capitão Manuel de Souza sob o título de Astúcias de Escapim. Molière foi também encenado em São Paulo, pois na segunda década do século XIX, o viajante francês Saint Hilaire assistiu a uma montagem do Avarento, descrita com detalhes em seus relatos de viagem. Há indícios de que Antônio José de Paula, ator e empresário português que traduziu e encenou Cinna, de Corneille, e Mahomet, de Voltaire, tenha estado no Brasil em tournée, por volta de 1790 , em especial no Rio de Janeiro. Na Bahia, que era a sede do vice-reinado até 1763 , a atividade teatral era uma prática constante que se expandiu posteriormente para o Rio de Janeiro. No interior, nas capitanias de Minas Gerais ou Mato Grosso, as encenações eram em grande número, pois vilas e cidades foram implantadas devido às riquezas geradas pelas descobertas de pedras preciosas e ouro A Igreja ainda desempenhava um papel relevante no teatro, com a representação de peças, cavalgadas, touradas, combates simulados, números musicais, fogos de artifício e desfile de carros alegóricos. Havia também as manifestações privadas, que permitiam uma ampla margem de improvisações nos espetáculos, muitas vezes com auxílio de títeres, sendo muito utilizados títeres de porta, que improvisavam os espetáculos de porta em porta e recolhiam o óbulo espontâneo dos que assistiam, dos títeres de capote - espetáculo ainda mais rudimentar e pitoresco e os títeres de sala, sistema teatral em evolução para o teatro de personagens vivos.(Cf. LUIZ EDMUNDO, 1932:526)

Como prova de que o teatro foi especialmente relevante nas artes cênicas do final do século XVIII, estão as Casas de Ópera do Brasil, e, em muitas delas, foram encenadas peças de Antônio José da Silva, o Judeu. O segundo edifício teatral de Salvador, o Teatro de Guadalupe, é mencionado no programa de festas (...) dando relevo às peças teatrais aclamadas na época, tais como Labirinto de Creta, Guerras do Alecrim e da Manjerona, Encantos de Medéia, do celebrado brasileiro Antônio José. "(HESSELe READERS, 1974:49). Os mesmos historiadores referem-se à ousadia do padre Ventura, que mandou construir, às suas expensas uma Casa da Ópera, no Rio de Janeiro, onde se representaram, sobretudo, peças de Antônio José da Silva, o Judeu .

\section{O teatro de Antonio Jose da Silva, o Judeu}

Persistia na cena e na dramaturgia, neste período ainda repleto de contradições e paradoxos no cenário brasileiro, a obra do dramaturgo Antonio José da Silva, o Judeu, (17051739), cujas peças fizeram imenso sucesso tanto na metrópole quanto na colônia. Tem-se o registro documental das seguintes encenações de suas peças no Brasil: a) No Tejuco, em Minas Gerais, no teatro da Chácara de Chica da Silva, onde foram encenadas duas peças de Antônio José: Encantos de Medéia e Anfitrião ou Júpiter e Alcmena; b) Segundo depoimento de um Membro da Academia dos Renascidos da Bahia, Francisco Calmon, em publicação lisboeta de 1762, afirma que nas festividades do casamento da princesa D. Maria com D. Pedro, infante de Portugal, em outubro de 1760 foram apresentadas as comédias Porfiar Amando, da qual não se conhece o autor, e a ópera O Anfitrião, de Antonio José. O historiador do teatro Galante de Souza diz ainda que na mesma ocasião, foram encenadas a óperas de Metastásio, Alexandre na Índia, Artaxerxes e Dido Abandonada. (SOUSA, 1960 v.2,: 131); c) Poucos anos 
depois, a Casa de Ópera do Padre Ventura, já referida - provavelmente a primeira Ópera dos Vivos no Brasil, foi incendiada em 1769, enquanto em seus palcos estava sendo encenada a peça Os Encantos de Medéia. Porém há registro de que outra peça sua foi encenada neste mesmo teatro, Guerras do Alecrim e da Manjerona. (SANTOS,s/d :162); d) Em Santo Amaro da Purificação, no recôncavo baiano, por ocasião da comemoração do enlace de Dona Maria, princesa do Brasil, com o infante de Portugal, encenou-se, com o financiamento dos funcionários da Justiça, a ópera Anfitrião, que, segundo Nelson Araújo não foi senão a peça do mesmo nome de Antônio José da Silva." (ARAÚJO, 1991: 182).

Como primeiro dramaturgo nascido em terras brasileiras, o Judeu tornou-se um clássico. Almejou e conseguiu racionalizar a cena portuguesa - que por muitas décadas, estivera dominada pelas comédias espanholas e pelas óperas italianas, como demonstra o quadro que elaboramos. Segundo Magalhães Junior, "o escritor popular por excelência, sabia arcabouçar suas peças, dar-lhes graça, movimento e vivacidade.”(MAGALHÃES JÚNIOR, 1957:1).

Pelo que pudemos observar, Antonio Jose sabia motivar as platéias, mesmo que muitas vezes suas peças demandassem maior nível de instrução. Segundo José Pereira Tavares as primeiras edições de algumas das peças do Judeu ocorreram em vida e de forma anônima por Antônio Isidoro da Fonseca, entre 1736 e 1737. (TAVARES, 1957-58). Entretanto, no Brasil, a maioria das encenações é posterior a 1760.

$\mathrm{Na}$ pesquisa que coordenei investigou-se a dramaturgia de Antônio José da Silva utilizando os pressupostos teóricos de Jean-Pierre Ryngaert (1996:36) na análise das peças Guerras do Alecrim e da Manjerona e Os Encantos de Medeia. Este teórico propõe, através de uma metodologia criada por ele, um estudo detalhado dos diversos componentes e das características gerais de um texto teatral, os quais devem estar diretamente relacionados com os componentes históricos. No que tange às investigações sobre o teatro de bonecos aprofundamos os estudos das peças Esopaiada e D. Quixote e Sancho Pança, utilizando como arcabouço teórico as obras de Patrice Pavis. (2003) E no estudo comparativo entre Antonio José e Molière, analisamos a peça Anfitrião visto que desde a Antiguidade clássica o tema tem servido de inspiração aos dramaturgos. Esta etapa beneficiou-se da metodologia de Flavia Corradin.(1998).

\section{Títeres ou humanos?}

Uma das discussões geradas pela pesquisa foi pesquisar se as peças de $\mathrm{O}$ Judeu foram sempre representadas por bonecos. Conseguimos perceber que as peças do Judeu representadas no Teatro do Bairro de Lisboa foram, provavelmente, encenadas por bonecos, fato também assim interpretado pelo estudioso José Pereira Tavares, pesquisador português da obra do Judeu, ao investigar a 'Dedicatória' e o 'Ao leitor desapaixonado', que precedem as edições integrais do teatro de Antônio José da Silva, e ainda por afirmações de uma ou outra figura das suas comédias. Esta pesquisa conclui que, em Portugal, as óperas eram encenadas por fantoches - "um dos aspectos do teatro popular, que já vinha de época anterior a Cervantes, autor do curiosissimo entremez - Retablo de las maravilhas."(TAVARES, 1957-58, p.XXIX).

Em Ao leitor desapaixonado, que é atribuído ao Judeu, encontramos expressões que se 
referem aos bonecos, tais como "os representantes (os atores) que se animam de impulso alheio", "sombras do inanimado”. (SILVA,1957-58:.6) Luciana Stegagno Picchio justifica do uso dos bonifrates ou fantoches como intérpretes de peças teatrais, porque eram "mais econômicos e manejáveis (...) menos perigosos do que seus confrades de carne e osso (pois estamos em pleno regime inquisitorial), os bonifrates portugueses não se limitavam a substituir os atores em dramas em que eles seriam suspeitos, mas solicitam também aos autores, inspirando-lhe peças que só mesmo bonecos seriam capazes de representar" (PICCHIO, 1991: 182).

Na peça Os Encantos de Medéia há cenas mágicas e mirabolantes, as quais dificilmente poderiam ser encenadas por humanos devido aos poucos recursos do teatro na época. Sabese, entretanto, que a representação da ópera Anfitrião foi encenada por humanos pelos alunos da classe do Padre João Ribeiro de Lemos na Bahia, o que prova que nem sempre eram utilizados os bonecos. (ARAÚJO, 1991: 182).

Antônio José da Silva pode ser considerado precursor de um teatro brasileiro, pois sua obra já despontava algumas características estruturais de um gênero, "a comédia de costumes", que só se fixaria no Brasil um século mais tarde. Discordo que ele não abordava os costumes brasileiros e às vezes nem os costumes portugueses em suas peças, como afirmou Lafayette Silva, que defende o início de um teatro brasileiro- enfocando hábitos e tipos nacionais, somente a partir de Luiz Carlos Martins Pena, por ele considerado o legítimo criador da comédia nacional. (SILVA, 1938:131). È importante ressaltar que discordamos de Laffayette Silva, pois Antônio José da Silva o Judeu , brasileiro e fluminense, e transferiu-se para Lisboa por razões familiares, porém manteve em seus textos muitas expressões da colônia, como afirmam Cafezeiro e Gadelha.(1996:79)

A indicação a respeito do gênero da peça, que segue ao título (na edição de 1957, Rio de Janeiro, Ed. Civilização Brasileira) “comédia em duas partes”, é seguida de uma observação: "ópera joco-séria”. Esta notificação nos informa que há canto e música na peça. E, realmente, ela é toda permeada por árias. Mas essa observação, já traz em si um primeiro elemento de comicidade. Por apresentar-se, ao mesmo tempo, com duas características opostas: jocosidade e seriedade. No entanto, é importante lembrar que a palavra 'ópera' aplicava-se a qualquer peça que intercalasse trechos falados com números de canto, executando-se a parte musicada conforme os recursos locais. (PRADO, 2003: 24.)

As comédias segundo os modelos canônicos, como as de Molière, geralmente se dividem em três atos. Guerras do Alecrim e da Manjerona não é dividida em atos, mas em duas partes. "Partes" é uma nomenclatura diferente. No século XVIII os dramaturgos falam em atos ou quadros. Ela ainda possui subdivisões em cenas. A primeira parte possui quatro cenas e a segunda, sete. $O$ texto tem tantas divisões que chega a ser descontínuo, não obedecendo às unidades aristotélicas de ação, tempo e espaço. E as ligações entre as cenas também não se enquadram nas classificações apresentadas por Ryngaert: "ligação de presença' (saídas ou entradas), 'ligação de procura' (a personagem que entra em cena procura uma outra que sai), ‘ligação pelo ruído’ (a personagem é atraída por um ruído), 'ligação pelo tempo' (quando não há outra justificação a não ser uma necessidade horária)”. (RYNGAERT,1996: 41). As cenas em Guerras do Alecrim e da Manjerona não se justificam por uma necessidade horária, mas talvez por uma necessidade de se instaurar a cada cena um novo jogo e código de comicidade, que é 
independente dos demais. O que não significa que não haja ligação entre as cenas. Esta ligação existe, todas elas se encaminham para o fechamento da ação. Mas, se inaugura a cada cena um novo ritual de comicidade, o que provoca uma quebra na linearidade do encadeamento da ação. Ryngaert chama atenção para a utilização deste princípio de descontinuidade nas dramaturgias elisabetanas e francesas da primeira metade do século XVII. (RYNGAERT, 1996: 42). O que se passa fora do texto e do palco também é utilizado como um elemento ou como uma justificativa para a comédia. Em Guerras do Alecrim e da Manjerona, o texto foi elaborado em função da comicidade, "a intenção exclusiva do poeta era a galhofa, e tal galhofa que transcendia muita vez às raias da conveniência pública." (MACHADO de ASSIS, Antonio José, in: "Revista Brasileira", I, 1879).

O próprio Antonio José confessou que sua preocupação era o 'fazer rir' quando escreveu o seguinte num trecho de Ao leitor desapaixonado, quando se referia a sua obra: "Bem conheço que nelas acharás muitos defeitos: porém, como não pretendo singularizar-me nos meus escritos, te peço que nestas obras atendas somente ao desejo que tenho, de agradar-te e vejas não quero outro prémio (sic) mais que o que te peço nestas".(SILVA, Ao leitor apaixonado, 1957:5)

Em função deste objetivo, apelou para inverossimilhança e para uso, às vezes excessivo, do grotesco, fato que só o beneficia na história do teatro. Ele inovou quando utilizou a prosa em vez do verso, a música como complemento integrante da totalidade teatral; o recurso dos fantoches "como disfarce amortecedor do emprego reiterado da sátira que desconstrói os valores da pomposidade barroca". (PEREIRA, 2006:50)

\section{Até que ponto há semelhanças entre Antonio José e Molière?}

Muitas vezes a obra de Antonio José da Silva é comparada à de Molière pela proximidade do período em que viveram. Notam-se semelhantes construções cênicas no que concerne à farsa: esconderijos, disfarces, empregados espertalhões, etc. Sendo herdeiros da Comédia Nova, aproximam-se também na temática das peças: peripécias de jovens amantes para se casarem, opondo-se aos velhos e ajudados por criados ladinos. $\mathrm{Na}$ análise de Os Encantos de Medeia e Guerras do Alecrin e da Manjerona percebe-se que a temática amorosa é o foco principal, sendo indutora do enredo. A sátira às práticas medicinais, bem tradicionais no teatro, aparece tanto na obra de Molière, como nas peças do Judeu. Também há semelhanças na obra de ambos os autores no que concerne ao gênero cômico. No entanto, as peças de Molière possuem uma tipificação dos personagens como em $\mathrm{O}$ Avarento, ou tratam da condição social de determinado personagem, como ocorre em O Médico à Força e O Burguês Fidalgo. O desfecho de suas ações sempre revela uma moral. Em contrapartida, as personagens de Antonio José apenas indicam a tipificação, com um humor um tanto ingênuo, pois ele utiliza situações fatalistas para provocar o riso. Nem em Guerras do Alecrim e da Manjerona nem em Os Encantos de Medéia existe função moralizante, visto que os heróis geralmente são movidos por interesses financeiros. Como interpretou Machado de Assis, "o Judeu achou na aventura pagã o mesmo que lhe acharam Plauto, Molière e Camões (...) O nosso poeta seguiu no principal a fábula que encontrou nos seus antecessores, fazendo-lhes, todavia as alterações suscitadas pelo gosto próprio e das platéias". (MACHADO de ASSIS, 1879) 
Conclui-se que o teatro de Molière foi uma das referências de Antônio José. Mas não apenas ele, assim como o teatro francês em geral, o espanhol (não podemos esquecer que Portugal acabara de restituir sua autonomia em relação à Espanha) e, é claro, o português o influenciaram. Sobre esta questão, comentou José Pereira Tavares:

As suas composições receberam, sem dúvida, influência maior ou menor do teatro espanhol e do teatro francês. Do primeiro, além das peças de Lopes da Veiga, de Tirso de Molina e de Calderón de la Barca, devia o nosso autor conhecer as de Lope de Ruela (Pasos), de Cervantes (Entremezes), de Vélez de Guevara, Mira de Mescua, Francisco de Roxas (ou Rojas), Moreto, etc. Mais próximas dele, devem ter sido do seu conhecimento as coleções de peças - Musa Entretenida -, de Manuel Coelho da Rocha (1695) e - Musa Jocosa -, de Nuno Niscnio Sutil (1709). (...) Dos comediógrafos franceses, é natural que Antônio José da Silva conhecesse razoavelmente Molière, Marivaux, Regnard e Boursault.(TAVARES, 1957:.XXVIII)

Apesar de muitas dessas obras estarem ligadas entre si, tendo partido muitas vezes de estórias clássicas, Machado de Assis teoriza que "ainda que imitando ou recordando, o Judeu se conserva fiel à sua fisionomia literária; pode ir buscar a especiaria alheia, mas há de ser para temperá-la com o molho de sua fábrica” (MACHADO de ASSIS, 1879)

O Anfitrião de Molière foi apresentado pela primeira vez ao público a 13 de janeiro de 1668 no teatro do Palais-Royal na França. Inteiramente escrita em versos livres, não é considerada pelos críticos uma de suas melhores peças, embora muitos concordem que é nesta que o grande cômico se revela como versejador. Molière retoma esse antigo tema latino num momento em que, não apenas recebia a hostilidade de muitos setores da sociedade, cansados de se verem desnudados e ridicularizados em suas comédias, como também sofria a perseguição da censura eclesiástica, posto que já tinha escandalizado o clero com a peça Tartufo.

Antônio José da Silva, o Judeu, escreve Anfitrião ou Júpiter e Alcmena em 1736, sob uma inspiração que mescla a ópera italiana e o teatro de cordel. Embora suas peças tenham estrutura bem semelhante às comédias antigas greco-romanas, essa característica se soma com as da ópera. Nesta peça algumas árias são cantadas desde solos e duetos até corais, que surgem tanto como ilustração dos sentimentos dos personagens, como substituição dos diálogos formais, durante o curso da ação da cena. Este é o caso, por exemplo, do quadro em que os dois Anfitriões se confrontam: enquanto duelam, cantam uma ária: Júpiter, Anfitrião, Alcmena e Saramago, os dois primeiros lutam e os dois restantes tentam apartá-los, findando a cantoria e o embate com o desmaio de Alcmena. Do teatro de cordel, o Judeu retirou temas de entremezes e comédias, que revelam um tom farsesco e várias características populares.

Molière inspira-se inicialmente na Commedia dell'Arte, gênero popular do século XVI que extraía o cômico dos efeitos da caracterização dos personagens. Esse gênero baseava-se principalmente na construção do trabalho do ator, nos jogos de improvisação e no uso do corpo e da voz de modo estilizado e, por vezes, acrobático. Nesse ponto muito se assemelha a 
cena teatral construída por Molière, que colocava no centro a presença do ator. Certamente, isso se acentuava pelo fato do dramaturgo francês ter começado sua trajetória como ator para, posteriormente, tornar-se um homem de teatro, exercendo todas as funções que lhe são afetas. Aproveitando-se da leveza das improvisações, acrescentou crítica e mordacidade à comédia francesa, o que lhe engendrou desamores por parte de alguns grupos da sociedade. $\mathrm{O}$ autor francês criticava a burguesia em ascensão, os nobres decadentes, as solteironas, os varões apaixonados, as esposas incompreendidas, os maridos enganados, os beatos hipócritas e os médicos incompetentes; todos eram postos à crueza da representação.

Esse aspecto do teatro de Molière, essencialmente construído no ator, distancia-se do teatro do Judeu que consistia quase sempre num teatro de marionetes, aliás, muito em voga em Portugal na primeira metade do século XVIII. Esse período dos setecentos caracteriza-se por uma proliferação teatral que contrasta com a escassez do século anterior, e tem como destaque as Óperas Portuguesas, apresentadas nos teatros públicos do Bairro Alto e da Mouraria, em especial entre o ano de 1733 e 1741. (CÂMARA, 1996:32) O gênero nasceu da iniciativa do rei D. João V em custear os estudos dos músicos mais importantes de Portugal na Itália. Na terra estrangeira, estes músicos tiveram contato com a ópera italiana, destacando-se Antônio Teixeira, comprovadamente o compositor das operetas de Antônio José da Silva. (Luiz Blanco, apud TAVARES)

O teatro popular crescia, era o gosto do povo que ditava as características das montagens. Assim, o texto perdia um pouco sua importância e cedia lugar ao espetáculo de efeitos, recursos com maquinarias e galhofas. $O$ teatro do Judeu caracterizava-se pela dinâmica dos diálogos, riqueza das situações, espontaneidade e a simplicidade, como define Machado de Assis - "O nosso Judeu era a farsa, sem outras pretensões, sem mais remotas vistas que os limites de seu bairro e seu tempo" (MACHADO de ASSIS, 1906).

A obra do Judeu não se mostra tão engajada politicamente como a de Moliére. Não que lhe faltassem motivos para criticar a hipocrisia da sociedade; pois vivera desde a infância sob o sofrimento das perseguições dão Tribunal da Santa Inquisição, e talvez por isso não tenha se confrontado deliberadamente com a instituição em suas peças. Contudo, há momentos em suas obras, em que Antônio José dá vazão às suas opiniões, como em A vida do Grande D. Quixote de La Mancha e do Gordo Sancho Pança, em que o poeta não deixa de parafrasear os processos inquisitoriais e testamentários que marcaram sua vida. Também em Anfitrião, se expressa através da fala de Íris, "quem tanto pergunta é bom para inquisidor", ou noutro momento por Anfitrião que, preso, aguardando a execução de sua sentença de morte, clama por justiça: "Iustos deuses, por que não vos compadeceis de mim, que sou um inocente?" Alguns autores discordam que o Judeu expressasse suas idéias em seus textos, como Machado de Assis, que escrevera em artigo publicado: "não obstante o espetáculo do que padeciam os seus, as óperas de Antônio José não trazem (...) nenhum vislumbre do episódio trágico, salvo alguns versos do Anfitrião que se crêem (e, que quanto a mim, sem outro fundamento além da conjetura) como aplicáveis a ele mesmo." (MACHADO de ASSIS, 1906)

Antônio José era um poeta cômico com tendências burlescas, que segundo Machado de Assis, não escrevera nenhuma comédia perfeita, porém se destaca pela peça Guerras do Alecrim e Manjerona. Ao contrário das comédias de Molière que representavam um retrato de 
sua época, as óperas do Judeu eram, praticamente inspiradas na mitologia, com exceção das Guerras do Alecrim e Manjerona e da Esopaida ou Vida de Esopo, que refletem mais os costumes locais ou criticam a sociedade. As demais óperas de sua autoria apresentam temáticas mitológicas, como é o caso do Anfitrião.

Apesar de bem distintas, as vidas dos dois autores têm pontos similares ou inversamente proporcionais. Enquanto Molière recusa o emprego hereditário que lhe era garantido, de tapeceiro do rei, contrariando sua família, o Judeu dedica-se à advocacia juntamente com seu pai. Ambos acabam por conquistar a nobreza e a simpatia das respectivas monarquias de seu tempo, sendo que Molière primeiro alcança a plebe numa longa excursão pelo interior da França, para depois ganhar os palácios parisienses. O Judeu faz o caminho inverso. Ambos são perseguidos pela Igreja, é claro que, em proporções e conjunturas diferentes, Antônio José foi acusado de judaísmo, com prisões, penalidades e torturas. Molière conseguiu atritos com o clero pelas críticas que faz à Igreja, chegando a ser ameaçado de execução na fogueira, destino trágico do qual se livra com a revisão de Tartufo. Infelizmente o autor luso-brasileiro não conseguiu evitar a morte, decidida pela inquisição.

Antônio José escreveu apenas oito peças, número ínfimo frente à numerosa extensão da obra do francês. Muitos teóricos se perguntam se o Judeu chegaria a adquirir a grandeza e a maturidade artística de Molière se não tivesse deixado a vida prematuramente, ainda em idade tão produtiva. Talento e originalidade ele os tinha para isso. Outra questão levantada pelos estudiosos é se teria ou não Antonio José da Silva tido acesso às obras molierescas. Luiz Francisco Rebello afirma que Portugal teve estreito contato com os textos franceses. (REBELLO, 1972) e a tese de defendida na Universidade da Provence por Marie-Noelle Ciccia atesta a grande influência de Molière no teatro português e a grande admiração dos portugueses pelas peças francesas. (CICCIA, 2001)

Confrontando-se os Anfitriões dos dois autores, percebe-se que, de forma inconsciente, o Judeu tinha, diante dos olhos, a peça homônima de Molière. Pode ser destacado como ponto divergente, por exemplo, o caráter de Cornucópia e a situação dela com o marido, que só existiam na peça de Molière. Apesar de algumas divergências, algumas idéias são diretamente apropriadas por Antonio José, como podemos observar na cena em que Mercúrio, transformado em Sósia, encontra com Cleantis, de perfil semelhante nas peças dos dois autores. Quando existe uma paródia semelhante a esta, segundo Flávia Corradin, o autor busca não só retomar uma imagem já trabalhada como também propor alguma crítica ao texto que tomou como base. Esta crítica não trás em si o conceito de contradizer, mas sim, a proposição de um diálogo entre os dois autores, a inserção de novas idéias a fim de estabelecer um novo paradigma para a peça. Assim, o autor, mesmo sob influência, imprime sobre a obra marcas de sua época e de seu estilo literário.(CORRADIN,2001) A utilização neste estudo da transcrição comparativa das obras tem por finalidade observar exatamente as características de influência, diálogo e mesmo de negação entre os autores. A obra de Antonio José da Silva, apesar de mais extensa e com mais intrigas em sua trama, termina por ser mais dinâmica devido ao diálogo mais próximo do cotidiano, mais próximo do público.

Polemizamos com Machado de Assis quando afirma que "As óperas do Judeu eram dadas num teatro popular; não as ouvia a côrte (sic) de D. João V, mas o povo e os burgueses 
de Lisboa (...)", motivo pelo qual ele justifica que a linguagem utilizada também era popular . (ASSIS, Machado de. Antonio José, in: "Revista Brasileira”, I, 1879) No entanto, Ivo Cruz atesta que Antonio José faz uma síntese entre o teatro declamado, de cunho popular e a ópera, que era um espetáculo da corte. Acrescenta que apesar de ser uma sala popular, $\mathrm{O}$ Teatro do Bairro Alto recebia a aristocracia e a burguesia, pois a principal intenção das peças era, através dos bonecos, dirigir-se à classe dominante de seu tempo. (CRUZ, 1988: 16)

\section{A questão das partituras}

Por muito tempo havia dúvidas sobre quem teria escrito as partituras das 'óperas' do Judeu. Como releva o próprio autor em Ao Leitor Desapaixonado, na montagem de uma peça devem existir três colaboradores distintos; o autor do texto, o da música e o 'pintor' dos cenários: "Não há melhor ouvinte do que o leitor desapaixonado, sem afecto (sic) ao autor da obra, sem inclinação ao da música, sem conhecimento do arquitecto (sic) da pintura."(SILVA, 1957-58: 5). Entretanto as dúvidas foram dissipadas. O estudioso José Pereira Tavares alega que, apesar dos antigos historiadores do teatro português como Teófilo Braga acreditarem que a música também fora composta por Antonio Jose, em 1947 o falecido compositor e musicólogo Luís de Freitas Branco descobriu as partituras de Antônio Teixeira, no arquivo do Paço Ducal de Vila Viçosa, .e de fragmentos da música das Variedades de Proteu." (Cf. TAVARES, 1957-58, .XXXI - XXXIII).

Em Os Encantos de Medeia, os personagens e o enredo são inspirados nos clássicos e utilizam "cacos" de outras obras. Aliás, esta é uma das características da obra de Antonio José. Uma das poucas exceções a essa regra é Guerras do Alecrim e da Manjerona, considerada por Machado de Assis como uma das melhores comédias do século XVIII, comparável às obras de Molière e Gil Vicente. Para não faltar nada, há também aforismos latinos, e até uma copia latina, digna de Molière. De fato, exceto Guerras do Alecrim e Manjerona, todas as suas outras peças possuem temas ou fazem referências a obras já existentes. Cafezeiro e Gadelha explicam bem o motivo dessas inspirações, considerando que a obra é "plena de metáforas, apagamentos e desvios de sujeitos que marcam a pressão política sofrida pelo seu discurso. Tudo se encobre, cobre e disfarça na sua expressão, como quem tem sobre a cabeça uma perseguição desmesurada e infame. Dai a universalidade de seus temas, escondidos no manto da mitologia, da burla, da cultura popular." (CAFEZEIRO e GADELHA, 1996: 79-80)

Talvez isto possa ser considerado uma verdade, porém naquela época "A comédia era (...) uma forma pouco legitimada da arte, portanto deixada em relativa liberdade para abordar, até por convenção de gênero, aspectos considerados indignos do grande teatro" (ARÊAS, 1987: 151) O próprio dramaturgo fez essa diferenciação entre a comédia e a tragédia: "o estilo sublime e elevado só se permite nas tragédias, em que se trata de cousas graves e nimiamente sérias, (...). Na comédia, porém, há-de ser o estilo doméstico, sem afectação (sic.) de sublime” (SILVA 1957-58: 6.)

Possivelmente transparece em sua obra a pressão política sofrida em seu discurso por ele ter sido um homem perseguido desde muito jovem. No entanto, não foram suas peças a causa da sua condenação, ao contrário do que supõem alguns historiadores. A pesquisa 
revelou que não foram as peças livres e grotescas, que por vezes se aproximavam do teatro popular que motivaram o suplício de Antonio José, mas sim sua origem racial.

Investigando os processos da Santa Inquisição na Lisboa do século XVIII, Evaristo de Morais, advogado da Sociedade Brasileira de Criminologia, esclareceu o fato quando publicou que:

Concorriam nobres, burgueses, clérigos, aos espetáculos, e ninguém se escandalizava com algumas facécias, um tanto livres. Há quem acredite terem certas irreverências de Antônio José fortemente contribuído para as perseguições inquisitoriaes (sic) com que foi victimado (sic), terminando na folgueira. Há engano. Não se vislumbra, através dos dois processos, a menor influência desse factor (sic), e - o que é mais - só se vislumbra, em depoimento de uma testemunha de defesa, rapida alusão a produção theatral (sic) do 'Judeu'. Accresce (sic) esta circunstancia, assignalada (sic) pelo abalisadissimo pesquisador J. Lucio de Azevedo: - 'Seis annos (sic) após a morte do poeta, um editor benemérito cuidou de dar á estampa as suas obras theatraes (sic). Estas, como tudo que se imprimia em Portugal, tiveram que passar pela censura da Inquisição e da autoridade ecclesiástica (sic). O cónego (sic) D, José Barbosa, pelo diocesano, informou sobre as óperas: - Não têm cousa alguma contra a fé e bons costumes'. O dominico Fr, Francisco de Santo Thomaz pelo Santo Officio (sic): 'o sal destes escriptos (sic) foi com muita arte extraído dos mares da eloqüência, dentro das margens da modéstia, e sem redundância fora dos limites da religião cristã'. E deu licença para a impressão o mesmo Inquisidor Geral Nuno da Cunha, que ordenára a prisão do autor em 1737. (MORAES, s/d: 39-40.)

O teatro de Antonio José tráz o carnaval para o palco. A expressão grotesca - que não reconhece limite de hierarquia social entre o real e o fantástico, o sagrado e o profano-, está impregnada na obra deste autor tão encenado tanto em Portugal quanto no Brasil, que, como diria Bahktin, estaria usando seus próprios cronotopos. (REBELLO, 1972).

Antônio José foi inegavelmente competente como autor, possivelmente o mais encenado de língua português no século XVIII. Seu teatro, representado seja por bonecos ou por atores, influenciou a "inauguração" de um teatro e um gênero, a comédia de costumes, brasileiros. Vilma Arëas, reconheceu a obra do Judeu como fonte inspiradora do teatro Martins Pena, especialmente no texto extraído da Parte II, cenas 4 e 5, da Vida do Grande D. Quixote de la Mancha e do Gordo Sancho Pança, de Antônio José da Silva, o Judeu."(ARÊAS, 1987). Curiosamente a primeira tragédia brasileira encenada em 1838 por João Caetano foi Antônio José ou o Poeta e a Inquisição de José Gonçalves de Magalhães.

\section{Outros autores encenados no Brasil}

Apesar da história do teatro de Cafezeira destinar apenas uma página à dramaturgia dos poetas e dramaturgos mineiros, discordamos que as dramaturgias tenham sido apenas 
as citadas em todas as obras, preferimos concordar com Afonso Ávila, que Cláudio Manuel da Costa foi encenado muitas vezes nas Casas de Opera. Num documento datado de 1759, o próprio poeta Cláudio Manuel da Costa atestou que entre suas obras se encontravam: "poesias dramáticas, já então representadas em Vila Rica e no Rio de Janeiro,..." , além de "varias traduções dos dramas de Metastásio".(in AZEVEDO, José Afonso Mendonça de, Cláudio Manuel da Costa; conferência realizada no instituto geographico e histórico de Minas Gerais, a 4 de Julho/1929, p. 6)

Vale chamar a atenção para o fato de que na época em questão os escritores e poetas mineiros se encontravam submetidos a uma rigorosa censura da metrópole, que impedia que qualquer texto fosse publicado na colônia. Os intelectuais do século XVIII tiveram de aprender a conviver com a censura. Nenhum escrito era impresso no Brasil e, em Portugal, só se publicava com a obtenção prévia do parecer favorável da censura, um tribunal cujo intuito era proteger os interesses da igreja e do estado. (LUCAS, 198: 12) Tivemos, pois, uma verdadeira plêiade de poetas a agir sob suspeita. Lucas nos remete a existência de uma Arcádia mineira, um grupo de poetas e escritores que se encontravam regularmente para compartilhar suas idéias e obras. Lothar Hessel e Georges Raeders, ao falarem da Casa de Ópera de Vila Rica afirmam que foi possivelmente nesse teatro que os poetas e, por vezes suas esposas, se reuniam para assistir à leitura ou à representação de peças, em prosa ou verso, de Cláudio Manuel da Costa, por exemplo, que teve várias delas representadas noutras vilas de Minas e mesmo no Rio de Janeiro.(HESSEL \&RAEDERS, 1974: 58)

Em sua tese, Fábio Lucas afirma o envolvimento do poeta Cláudio Manuel da Costa com o teatro de forma bastante clara E o poeta continua pioneiro nas reflexões teóricas acerca do "estado da arte", pois o prólogo ao leitor impresso a frente das Obras poéticas constitui (como nota Wilson Martins) o 1o manifesto literário brasileiro. Pioneiro, ainda, foi Cláudio Manuel da Costa no teatro, na cartografia (...) como tradutor documentado, já que transpôs ao português, peças dramáticas de Metsatásio. (LUCAS, 1998: 90)

Segundo Teófilo Braga em seu livro A Arcádia lusitana: Garção, Quita, Figueiredo, Diniz, o nome de Cláudio Manuel consta na lista de integrantes da Arcádia Romana, um movimento que "procurava restaurar o estylo de Petrarcha" e que teve início em fins do século XVII, na Itália, influenciando muitos movimentos literários ao longo do século XVIII, por toda a Europa. (BRAGA, 1899: 49). Nesta associação literária o poeta mineiro recebeu o pseudônimo de Glauceste Saturnino, codinome com o qual assinou várias publicações.

Em Portugal, os movimentos literários do século XVIII buscaram, em sua maioria, seguir uma estética seiscentista, enaltecendo o decoro e a vida palaciana da corte de Dom João V. Em 1745, momento em que muito possivelmente Cláudio Manuel se encontrava na metrópole para cumprimento de seus estudos superiores, surge um movimento denominado Academia dos occultos que se inspirou diretamente nos princípios da Arcádia Romana e buscou um resgate dos clássicos franceses e da estética quinhentista. Teria sido este movimento o precursor da Arcádia Lusitana, que seguindo o mesmo objetivo de um retorno aos clássicos se inspirava em autores como Sá de Miranda, Camões, Ferreira e Bernardes.

Quando foi fundada a Arcádia Lusitana em 1756, Cláudio Manuel da Costa já estava no Brasil. Entretanto, é possível que tenha feito parte da sociedade literária que precedeu aquela 
Arcádia, a Academia dos Occultos. Ao que indica sua biblioteca, o poeta mineiro inspiravase na literatura clássica pois apreciava Virgílio, Lucano, e outros clássicos da latinidade, Metastásio, Petrarca e Ariosto. Ora camoneano, ora poderoso descritivo, ora litúrgico pagão, ou místico do enlevo cristão, Cláudio Manuel da Costa oferece uma variedade tão grande em suas criações literárias, que seria impossível tentar classificá-lo. Para Cruz, os árcades se identificavam com o despotismo iluminado, mas burguês é ainda a própria essência de seu pensamento, bem como dos ideais igualitários. (CRUZ, 1998: 27) Entre os modelos que inspiraram Costa figuram autores que escreveram para teatro, o que contribui para confirmar sua poesia para serem declamada no teatro, como era hábito entre os clássicos.

No poema épico Vila Rica, de 1773, Cláudio Manuel narra os acontecimentos que levaram ao surgimento da cidade de Vila Rica, e muitas vezes o narrador assume o papel de diversos personagens, estabelecendo diálogos entres eles, todos em 1o pessoa. Inúmeros poemas e éclogas escritos como diálogos foram interpretados nesta pesquisa, e estamos certos de que muitos deles foram encenados na Casa de Opera de Vila Rica, da qual Costa era o principal incentivador ${ }^{3}$.

Para Cafezeiro e Gadelha, Caldas Barbosa, mulato, filho de português com escrava, sócio da Arcádia de Roma e um dos fundadores da Academia de Belas Letras de Lisboa, debateu com Bocage, a quem satirizou, pois ele compôs vários versos criticando o brasileiro. Caldas Barbosa é autor de duas pecas teatrais a Saloia namorada publicada em 1793 e a Vingança da cigana publicada e encenada no teatro São Carlos de Lisboa em 1794. Percebi na leitura dos textos de Barbosa a presença de descrições de cenários e rubricas, a divisão de cenas, a intercalação de trechos cantados diálogos tão incisivos e rápidos, bem diferentes dos discursos compridos da dramaturgia barroca. Ele coloca sempre personagens negros ou mulatos, inserindo inclusive diálogos em dialetos africanos, valorizando sua origem negra. Segundo Tinhorão, foi ele quem introduziu a modinha em Portugal e quando retornou ao Brasil, formou um reduto de afro-descendentes, contribuindo para uma dramaturgia mais brasileira. (Cf. TINHORÃO, 1998).

\section{Algumas considerações}

Como conclusão desta etapa da pesquisa Estudos do Espaço Teatral, considero que o teatro do final do século XVIII oscilava entre o aberto e pictórico do barroco, representado por dramas de Metastásio, encenações de clássicos europeus adaptados ao gosto português e as óperas de Antonio José, e o teatro declamado dos árcades mineiros. Segundo Antonio Candido, a mistura típica de nossos ilustrados é o pombalismo, o nativismo e a confiança nas luzes.(CANDIDO, 1964, v. 1: 48). E houve muitos protestos, como o de Caldas Barbosa e de o Judeu, o primeiro preso e o segundo morto pela Inquisição. Constatamos que a formação dos letrados, antes quase que restrita aos bacharéis e padres aumentou muito com os egressos de Coimbra, Edimburgo ou Montpellier, locais onde o teatro no século XVIII era estudado, produzido e freqüentado.

Pelo que se deduz dos documentos de época, os promotores de espetáculos teatrais na colônia não conseguiam facilmente os textos das óperas, comédias e outras peças a serem 
encenadas. O contratador Souza Lisboa aproveitou-se da experiência anterior do Tejuco para contratar libretos em Lisboa e solfas na própria capitania, ainda permutando peças com os operistas de São João Del Rei, vila onde também houve expressivo impulso para o teatro. Boa parte do repertório deve ter vindo de Lisboa, e, quanto aos originais estrangeiros, dali também viriam já traduzidos. No século XVIII, alguns poetas que moravam ou nasceram no Brasil começariam a traduzi-los com maior freqüência, como pude constatar na adaptação e tradução feita por Cláudio Manuel da Costa para o Demoofonte em Trácia de Metastásio, localizado no Arquivo Público Mineiro.

Concluiu-se também que o teatro de Antonio José da Silva, o mais recorrente em várias capitanias do Brasil setecentista, pode ser considerado esteticamente mais barroco do que clássico, visto que despreza as unidades de tempo e de lugar e apresenta um grande dinamismo nas ações dos personagens, que influenciaria futuramente a designação bibliográfica do "teatro de cordel".

Levantamento de parte do Repertório Teatral encenado no Brasil entre 1711 e 1822

\begin{tabular}{|c|c|c|c|}
\hline Obra & Autor & Ano de Representação & Local de Representação \\
\hline Comédias & & 1711 & Olinda e Recife \\
\hline Tragicomédia & & 1723 & Olinda \\
\hline El Conde Nicanor & Calderón de la Barca & 1717 & Bahia \\
\hline Effectos de Odio y Amor & Calderón de la Barca & 1717 & Bahia \\
\hline La Monja Alférez & Calderón de la Barca & 1718 & $\begin{array}{c}\text { Convento do Desterro na } \\
\text { Bahia }\end{array}$ \\
\hline Los Juegos Olímpicos & Calderón de la Barca & agosto de 1729 & Praça Pública da Bahia \\
\hline Fineza contra Fineza & Calderón de la Barca & agosto de 1729 & Praça Pública da Bahia \\
\hline La Fiera, el Rayo y la Piedra & Calderón de la Barca & agosto de 1729 & Praça Pública da Bahia \\
\hline Duas Comédias & & 1729 & Tablado Público em Cuiabá \\
\hline Concórdia & Gabriel Malagrida & 1731 & Maranhão \\
\hline El secreto a voces & Calderón de la Barca & 1733 & Praça publica Vila Rica \\
\hline El príncipe prodigioso & Calderón de la Barca & 1733 & Praça publica Vila Rica \\
\hline Hercules Galicus & Aleixo Antônio & 1739 & Colégio do Pará \\
\hline Porfiar Amado & Zorilho Rojas & $17 ? ?$ & Bahia \\
\hline O Anfitrião & Antônio José (Judeu) & $17 ? ?$ & Bahia \\
\hline Labirinto de Creta & Antônio José (Judeu) & $17 ? ?$ & Bahia \\
\hline Aspazia na Syria & Metastásio & $9 / 08 / 1740$ & Cuiabá \\
\hline $\begin{array}{c}\text { Eurene Perseguida e } \\
\text { Triunfante }\end{array}$ & Anônimo & $11 / 08 / 1740$ & Cuiabá \\
\hline O Saloio Cidadão & & $14 / 08 / 1740$ & Cuiabá \\
\hline Zenobia no Oriente & Metastásio & $16 / 08 / 1740$ & Cuiabá \\
\hline
\end{tabular}




\begin{tabular}{|c|c|c|c|}
\hline Inez de Castro & & $18 / 08 / 1740$ & Cuiabá \\
\hline Tamerlião na Pérsia & Metastásio & $26 / 09 / 1740$ & Cuiabá \\
\hline \multicolumn{4}{|l|}{ O Amor e a Ambição } \\
\hline ou Precepicio de Faetonte & Antônio José (Judeu) & $23 / 08 / 1740$ & Cuiabá \\
\hline Conde Alarcos & Anônimo & $24 / 08 / 1740$ & Cuiabá \\
\hline Tragédia de focas & & $3 / 09 / 1740$ & Cuiabá \\
\hline Entremez do Sganarelo & Adaptação de Molière & $3 / 09 / 1740$ & Cuiabá \\
\hline O Tutor Enamorado & & $29 / 09 / 1740$ & Cuiabá \\
\hline Tamerlão & & $25 / 08 / 1741$ & Cuiabá \\
\hline opera & Metastásio & 1750 & $\begin{array}{c}\text { Convento da Ajuda no Rio } \\
\text { de Janeiro }\end{array}$ \\
\hline La Sciencia de Reynar & & $14 / 02 / 1752$ & Pernambuco \\
\hline Cueba y Castillo de Amor & & $16 / 02 / 1752$ & Pernambuco \\
\hline La Piedra Philosophal & & $18 / 02 / 1752$ & Pernambuco \\
\hline Alexandre na Índia & Metastásio & $22 / 10 / 1760$ & Bahia \\
\hline Artaxerxes & Metastásio & $23 / 10 / 1760$ & Bahia \\
\hline Dido Abandonada & Metastásio & $25 / 10 / 1760$ & Bahia \\
\hline O Parnaso Obsequioso & Cláudio Manuel da Costa & $05 / 12 / 1768$ & $\begin{array}{c}\text { Palácio dos } \\
\text { Governadores(Vila Rica) }\end{array}$ \\
\hline Encantos de Medéia & Antônio José (Judeu) & 1753 a 1771 & $\begin{array}{c}\text { Teatrinho da Chica da Silva } \\
\text { (Tejuco) }\end{array}$ \\
\hline Anfitrião & Antônio José (Judeu) & 1753 a 1771 & $\begin{array}{c}\text { Teatrinho da Chica da Silva } \\
\text { (Tejuco) }\end{array}$ \\
\hline Porfiar Amando & & 1753 a 1771 & $\begin{array}{l}\text { Teatrinho da Chica da Silva } \\
\text { (Tejuco) }\end{array}$ \\
\hline Chiquita & & 1753 a 1771 & $\begin{array}{c}\text { Teatrinho da Chica da Silva } \\
\text { (Tejuco) }\end{array}$ \\
\hline Pelo Amor de Deus & & 1753 a 1771 & $\begin{array}{l}\text { Teatrinho da Chica da Silva } \\
\text { (Tejuco) }\end{array}$ \\
\hline $\begin{array}{l}\text { Guerras do Alecrim e } \\
\text { Manjerona }\end{array}$ & Antônio José (Judeu) & 1769 & Bahia \\
\hline $\begin{array}{l}\text { Cinco comédias e duas } \\
\text { Óperas }\end{array}$ & & Julho de 1769 & $\begin{array}{c}\text { Tablado armado na rua em } \\
\text { Cuiabá }\end{array}$ \\
\hline $\begin{array}{l}\text { Mais Vale Amor Q'Um } \\
\text { Reyno }\end{array}$ & & $21 / 08 / 1770$ & São Paulo \\
\hline $\begin{array}{c}\text { Vencer Traições com } \\
\text { Enganos e Disfarçar no } \\
\text { Querer }\end{array}$ & & $22 / 08 / 1770$ & São Paulo \\
\hline A ciganinha & & 1771 & Casa de Opera de Vila Rica \\
\hline Coriolano & & 1771 & Casa de Opera de Vila Rica \\
\hline
\end{tabular}




\begin{tabular}{|c|c|c|c|}
\hline Jogos Olímpicos & & 1771 & Casa de Opera de Vila Rica \\
\hline Alexandre na Índia & & 1771 & Casa de Opera de Vila Rica \\
\hline Óperas e Comédias & Antônio José (Judeu) & $4 / 10 / 1772$ & Cuiabá \\
\hline São Bernardo & Cláudio Manuel da Costa & 1775 & Casa de Opera de Vila Rica \\
\hline Encantos de Medéia & Judeu Antônio José (Judeu) & 1776 & $\begin{array}{l}\text { Casa de Ópera do Padre } \\
\text { Ventura, Rio de Janeiro }\end{array}$ \\
\hline Comédias & Comédias de Molière & 1776 & Teatro de Manuel Luiz (RJ) \\
\hline Comédias & Carlo Goldoni & 1776 & Teatro de Manuel Luiz \\
\hline óperas & Metastásio & 1776 & Teatro de Manuel Luiz \\
\hline Merope & Maffei & 1776 & Teatro de Manuel Luiz \\
\hline Enéias no Lácio & Alvarenga Peixoto & 1776 & Teatro de Manuel Luiz \\
\hline Várias peças & Antônio José (Judeu) & 1776 & Teatro de Manuel Luiz \\
\hline Enéias no Lácio & Alvarenga Peixoto & 1776 & Pará \\
\hline Demoofonte em Trácia & Metastásio & 03/12/1777 & Pará \\
\hline Dido Desprezada & Metastásio & 03/12/1777 & Pará \\
\hline Destruição de Catargo & Metastásio & 03/12/1777 & 03/12/1777 \\
\hline $\begin{array}{c}\text { O mais Heróico Segredo ou } \\
\text { Artaxerxes }\end{array}$ & Metastásio & 03/12/1777 & Pará \\
\hline Representações teatrais & & 1778 & Rio de Janeiro \\
\hline Amor Mal Correspondido & Luís Alves Pinto & 1780 & Casa da Ópera de Recife \\
\hline Óperas públicas & Diversos autores & & $\begin{array}{l}\text { Mariana, Sabará, Pitangui, } \\
\text { São João Del Rei }\end{array}$ \\
\hline $\begin{array}{c}\text { Guerras do Alecrim e } \\
\text { Manjerona }\end{array}$ & Antônio José (Judeu & 1785 & Mato grosso \\
\hline Esio em Roma & Metastásio & $21 / 09 / 1788$ & Recife \\
\hline A Gratidão & & 1790 & Pernambuco \\
\hline Zaira & Voltaire & agosto de 1790 & Cuiabá \\
\hline Ésio em Roma (ópera) & Metastásio & agosto de 1790 & Cuiabá \\
\hline Le Mariage Forcé & Molière & $21 / 04 / 1792$ & Rio de Janeiro \\
\hline Drama recitado & $\begin{array}{l}\text { José Eugênio de Aragão e } \\
\text { Lima }\end{array}$ & 1794 & Grão Pará \\
\hline Esio em Roma & Metastásio & & Grão Pará \\
\hline Zenóbia & Metastásio & & Grão Pará \\
\hline A Beata Fingida. & & & Grão Pará \\
\hline Opera publica & & $28 / 07 / 1800$ & Praça pública de Sabará \\
\hline Triunfo da América, & & $23 / 05 / 1810$ & Teatro de Manuel Luis \\
\hline Ópera vista por John Mawe & & 1810 & Casa de Opera de Vila Rica \\
\hline Escola de maridos & Molière & 1811 & Casa de Opera de Vila Rica \\
\hline
\end{tabular}




\begin{tabular}{|c|c|c|c|}
\hline Batalha de Saragoça & & 1811 & Casa de Opera de Vila Rica \\
\hline Peão Figalgo & Molière & 1811 & Casa de Opera de Vila Rica \\
\hline Dido abandonada & Metastásio & 1815 & Praça PúblicaTejuco \\
\hline Opera pública & & 1817 & Sabará \\
\hline O salteador & & 1818 & Praça PúblicaTejuco \\
\hline Ópera vista por Luccock & & 1818 & Casa de Opera de Vila Rica \\
\hline Zelo d'Amor & & 1819 & Teatro de Sabará \\
\hline $\begin{array}{l}\text { Maria Tereza,primeira } \\
\text { Imperatriz da Austria }\end{array}$ & & 1819 & Teatro de Sabará \\
\hline Inês de Castro & Antonio Ferreira & 1820 & Casa de Opera de Vila Rica \\
\hline Donzela de Marienburg & Antonio Xavier & 1820 & Casa de Opera de Vila Rica \\
\hline A vestal & Du Bocage & $13 / 5 / 1817$ & Real Teatro São João \\
\hline Aureliano em Palmira & Rossini & $25 / 04 / 1820$ & Real Teatro São João \\
\hline Camila & Paer & $12 / 10 / 1818$ & Real Teatro São João \\
\hline Coriolano & Niccolini & $13 / 5 / 1818$ & Real Teatro São João \\
\hline AS duas Gêmeas & José maurício & $17 / 12 / 1809$ & Teatro Régio \\
\hline Artaxerxes & Metastasio/ Marcos Portugal & $17 / 12 / 1812$ & Teatro Régio \\
\hline Axur, rei de oOrmuz & Salieri & $17 / 12 / 1814$ & Real Teatro São João \\
\hline D. Giovanni & Molière/Mozart & $20 / 9 / 1820$ & Real Teatro São João \\
\hline O barbeiro de Sevilha & Beaumarchais/Rossini & $21 / 07 / 1821$ & Real Teatro São João \\
\hline Caçada de Henrique IV & Puccita & $22 / 1 / 1819$ & Real Teatro São João \\
\hline Ouro não compra amor & Marcos Portugal & $17 / 12 / 1811$ & Teatro Régio \\
\hline Merope & MaffeiMarcos Portugal & $8 / 11 / 1817$ & Real Teatro São João \\
\hline
\end{tabular}

O quadro sinótico obtido através de fontes primárias nas Bibliotecas Nacionais de Paris (Obras Manuscritas) e de Lisboa, bem como no Centro Calouste Gubenkian de Paris, na Bibliothèque des Arts du Spectacle, além dos Arquivos Públicos de Minas (Belo Horizonte) e da Bahia (Salvador), bem como na Casa de Contos, Museu da Inconfidência em Ouro Preto e Museu do Ouro em Sabará, no Real Gabinete Português de Leitura do Rio de Janeiro, no Instituto Histórico Geográfico do Brasil, acrescidas das inúmeras fontes secundárias consultadas sobre o tema, permite perceber que não existiu um "vazio teatral" no século XVIII, no Brasil.

\section{Notas}

\footnotetext{
${ }^{1}$ Este artigo é resultante da Pesquisa Institucional Estudos do Espaço Teatral (4a etapa), sob minha coordenação intitulada Arquitetura e Dramaturgia: do teatro jesuitico às Casas de Opera do século XVIII, desenvolvida no Laboratório de da UNIRIO. Conta com o apoio do CNPq e com a participação das bolsistas de iniciação científica Catarina
} 
Almeida, Luanda Rosin, Mirian Leobino e Tainá Vianna.

${ }^{2}$ Além do documento assinado por Costa, afirmando sua presença como autor nos palcos brasileiros, localizados em AZEVEDO, José Afonso Mendonça de, Cláudio Manuel da Costa; conferência realizada no instituto geographico e histórico de Minas Gerais, a 4 de Julho/1929, p. 6, também o contratador João de Souza Lisboa, que mandou erguer a Casa de Opera de Vila Rica, em carta de 1770, lamenta a perda de um dos atos da peça São Bernardo, de autoria de Cláudio Manuel da Costa, que teria ficado bastante preocupado quando soube do desaparecimento de uma das partes da peça. (ver o documento APM código 205 fls 45-46 DF).

${ }^{3}$ Tive oportunidade de ler e analisar mais de uma centena de peças de autores portugueses ou italianos e franceses adaptados ao gosto português no setor de Manuscriptos du Fonds Portugais( Manuscripts Occidentaux da Bibliothèque Nationale de France )em 2003, durante o pós-doutoramento.

\section{Bibliografia}

AZEVEDO, José Afonso Mendonça de, Cláudio Manuel da Costa; conferência realizada no instituto geographico e histórico de Minas Gerais, a 4 de Julho/ 1929, Belo Horizonte, imprensa official, 1929.

ARAÚJO, Nelson. História do Teatro. Empresa Gráfica da Bahia, Salvador, 1991.

ARÊAS, Vilma Sant'Anna. Na tapera de Santa Cruz: uma leitura de Martins Pena. São Paulo: Martins Fontes, 1987.

BAKHTIN, Mikhail. A cultura popular na idade média e no renascimento - o contexto de François Rabelais. 3. ed. São Paulo: HUCITEC; Brasília: Editora da Universidade de Brasília, 1993.

BRAGA, Teófilo, A Arcádia lusitana: Garção, Quita, Figueiredo, Diniz, Porto: Ed. Livraria Chardron, 1899.

CAFEZEIRO, Edwaldo e GADELHA, Carmem. O Século XVIII: um esclarecimento. In: História do Teatro Brasileiro, um percurso de Anchieta a Nelson Rodrigues.Editora UFRJ / EDUERJ FUNARTE, Rio de Janeiro, 1996, p.79.

CÂMARA, Maria Alexandra T. Gago da. Lisboa: espaços teatrais setecentistas. Lisboa: Livros Horizonte Ltda, 1996. CICCIA, Marie-Noelle. Le Théâtre de Molière au Portugal de 1737 à la veille de la Révolution Libérale. Université d'Aix-Marseille I- Université de Provence, 2001, thèse de Doctorat.

CANDIDO, Antonio. Formação da Literatura Brasileira. São Paulo: Livraria Martins Ed. 1964, v. 1.

CHARTIER, Roger. A história cultural entre práticas e representações. Editora Difel, Rio de Janeiro: 1990.

COSTA, Cláudio Manuel da, Obras Poéticas de Cláudio Manuel da Costa (Glauceste Saturnino), por João Ribeiro, Ed. H. Garnier, livreiro editor, 1903. Tomo I e II

CORRADIN, Flávia Maria. Antônio José da Silva, o Judeu: Textos versus (con) textos. São Paulo: Íbis,1998.

COSTA, Cláudio Manuel da, Villa Rica. Poema em dez cantos, de... Árcade Ultramarino com o nome de Glauceste Saturnino, 1773.

EDMUNDO, Luiz. O Rio de Janeiro no tempo dos vice-reis. Rio de Janeiro. Instituto Histórico Geográfico Brasileiro - IHGB, 1932.

GAUER, Ruth Chittó. A contribuição portuguesa para a construção da sociedade brasileira. In Revista da História das Idéias Vol 19 , Lisboa, 1997, pp567-591

HESSEL, Lothar e RAEDERS, Georges, O teatro no Brasil da colônia à regência, Porto Alegre, Universidade Federal do Rio Grande do Sul, 1974.

LIMA, Evelyn F. W. Teatro e Memória. Urdimento, 2004. pp.

LUCAS, Fábio, Luzes e trevas: Minas Gerais no século XVIII, Belo Horizonte, Ed. UFMG, 1998.

MACHADO DE ASSIS,. Antonio José, in: "Revista Brasileira”, I, 1879.

MAGALDI, Sábato. Panorama do teatro brasileiro. São Paulo. Difusão Européia do Livro, 1996.

MAGALHÃES JÚNIOR, R.. Introdução, In: Duas Comédias de Antônio José, o Judeu. Rio de Janeiro, Civilização Brasileira, 1957.

MOURA, Carlos Francisco. O teatro no Mato Grosso no século XVIII. Belém: SUDAM, 1976.

NOVAIS, Fernando (diretor da coleção). História da Vida Privada no Brasil, volume I. Rio de Janeiro, Cia. das Letras, 1997. 
PAIXÃO, Múcio da. O Theatro no Brasil. Rio de Janeiro: Brasília editora, s.d.

PAVIS, Patrice. A análise dos espetáculos. São Paulo. Perspectiva, 2003.

PEREIRA, Paulo Roberto. A música e a marionete na comédia de Antonio José, o Judeu.. Revista Convergência Lusíada, n. 22, pp. 49-64.

PICCHIO, Luciana Stegagno, cit. In: História do Teatro. Empresa Gráfica da Bahia, Salvador, 1991.

PRADO, Décio de Almeida. História Concisa do Teatro Brasileiro. São Paulo, EDUSP, 2003.

REBELLO, Luiz Francisco. História do Teatro Português. Lisboa. Publicações Europa-América, 1972, 2a edição. (1a edição em 1968). aber.

RYNGAERT, Jean-Pierre. Introdução à análise do teatro. Tradução: Paulo Neves, Revisão de Tradução: Mônica Stahel. São Paulo: Martins Fontes, 1996, p.36.

SANTOS, Joaquim Felício dos. Memórias do Distrito Diamantino, 3a ed.,1978.

SILVA Antônio José da. Ao leitor desapaixonado; in: Obras Completas: Antônio José da Silva (O Judeu). Lisboa: Sá da Costa, 1957-58.

SILVA, Lafayette. História do teatro brasileiro. Serviço Gráfico do Ministério da Educação e Saúde. Rio de Janeiro, 1938.

SOUZA, J. Galante de. O Teatro no Brasil, Tomo I. Instituto Nacional do Livro, Rio de Janeiro, 1960.

TAVARES, José Pereira, prefácio e notas; in: Obras Completas de Antônio José da Silva (O Judeu), Lisboa: Sá da Costa, $1957-58$ 